\title{
BRPKM
}

Buletin Riset Psikologi dan Kesehatan Mental

http://e-journal.unair.ac.id/index.php/BRPKM

e-ISSN: 2776-1851

ARTIKEL PENELITIAN

\section{Gambaran Penerapan Developmentally Appropriate Practice pada Pendidikan Karakter Pramuka Penggalang Usia Remaja Awal}

\author{
MOHAMAD NUR SETYO \& IWAN WAHYU WIDAYAT* \\ Fakultas Psikologi Universitas Airlangga
}

\begin{abstract}
ABSTRAK
Gerakan pramuka merupakan salah satu lembaga nonformal yang mendidik karakter peserta didiknya. Namun, kondisi di lapangan pendidikan karakter pramuka tidak berjalan dengan optimal karena dalam penerapannya tidak sesuai dengan usia perkembangan peserta didik. Penelitian ini menjelaskan berbagai metode pendidikan karakter yang sesuai developmentally appropriate practice dan faktor apa saja yang mempengaruhi berjalannya pendidikan karakter di pramuka SMP. Penelitian ini menggunakan pendekatan kualitatif dengan tipe studi kasus intrinsik. Penelitian ini dilakukan pada tiga pembina pramuka penggalang. Teknik pengumpulan data penelitian ini menggunakan wawancara dengan pedoman umum. Teknik analisis data yang digunakan yakni analisis tematik dengan pendekatan data-driven. Hasil penelitian menunjukkan bahwa pendidikan karakter yang sesuai dengan perkembangan peserta didik dilakukan dengan metode yang tepat dengan memperhatikan minat dan potensi peserta didik, serta memperhatikan faktor yang dapat mempengaruhi jalannya pendidikan karakter pramuka.
\end{abstract}

Kata kunci: developmentally appropriate practice, karakter, pramuka

\begin{abstract}
The scout movement is a non-formal institution that educates the character of its students. However, the condition in the field does not run optimally due to it being in contrast to the developmental age of the students. This study describes methods of character education based on developmentally appropriate practice and what factors influence of character education in junior high school scouts. This research uses a qualitative approach with an intrinsic case study type. This research was conducted on three junior scout raisers. The data collection technique of this research used interviews with general guidelines. The data analysis technique used is thematic analysis with a data-driven approach. The results showed that character education in accordance with the development of students was carried out with paying attention to the interests and potential of students, as well as paying attention to factors that could affect the course of scout character education.
\end{abstract}

Keywords: character, developmentally appropriate practice, scout

Buletin Penelitian Psikologi dan Kesehatan Mental (BRPKM), 2021, Vol. 1(1), 1015-1029

*Alamat korespondensi: Fakultas Psikologi Universitas Airlangga, Kampus B Universitas Airlangga Jalan Airlangga 4-6 Surabaya 60286. Surel: iwan.widayat@psikologi.unair.ac.id 
sehingga penggunaan, distribusi, reproduksi dalam media apapun atas artikel ini tidak dibatasi, selama sumber aslinya disitir dengan baik.

\section{PE N D A H U L U A N}

Sejak lahir manusia membawa potensi alami yang perlu ditumbuhkembangkan. Oleh karena itu, diperlukan pendidikan untuk mengembangkan potensi alamiah yang dimiliki manusia secara optimal dan dapat melaksanakan tugas maupun tanggung jawabnya sebagai khalifah di bumi (Ahmadi, 2014). Definisi pendidikan sendiri menurut Undang-undang Nomor 20 (2003) tentang pendidikan adalah usaha sadar dan terencana dalam menciptakan suasana dan proses pembelajaran. Penting untuk disadari bahwa pendidikan memiliki pengaruh besar pada pengembangan diri dan kualitas seseorang. Melalui proses pendidikan, manusia belajar ilmu pengetahuan untuk wawasannya dan agar diterima oleh masyarakat.

Pendidikan merupakan proses pembudayaan, dimana pendidikan tersebut membuat manusia lebih baik secara akal dan moral. Manusia yang memiliki pendidikan dan wawasan luas akan menghasilkan budaya yang baik pula. Objek dan subjek dari kebudayaan adalah manusia itu sendiri sehingga antara manusia, pendidikan, dan budaya tidak bisa pisahkan. Pendidikan tidak hanya mengajarkan pengetahuan, pemahaman, dan keterampilan kepada peserta didik saja. Namun, pendidikan menghasilkan perubahan pada norma, nilai, sikap dan perwujudan (Dahama dan Bhatnagar, 1981:3, dalam Ahmadi, 2014).

Sebuah pendidikan formal, setiap usia mendapatkan jenjang pendidikan yang berbeda-beda. Mulai dari pendidikan usia dini hingga pendidikan perguruan tinggi. Hal tersebut dilakukan karena melihat dari kebutuhan belajar dan kemampuan peserta didik. Anak usia 10 tahun tidak mempelajari materi anak usia 17 tahun. Akan berbahaya jika hal itu dipaksakan karena dapat membuat anak stres dan tidak ingin belajar. Penting dalam pendidikan untuk menerapkan praktik yang sesuai dengan perkembangan (developmentally appropriate practice) sehingga kebutuhan belajar anak dapat tercukupi dan potensi mereka dapat terasah dengan baik.

Di Indonesia pendidikan tidak lepas dari pendidikan karakter atau pendidikan budi pekerti. Bapak Psikologi Indonesia, Slamet Imam Santoso mengatakan bahwa pembentukan karakter adalah tujuan dari pendidikan itu sendiri, dimana pendidikan mengembangkan potensi individu dan membuat individu dapat bertahan dalam masyarakat kelak (Santoso, 1981). Meskipun pendidikan karakter merupakan hal yang mutlak ada dalam suatu pendidikan, pendidikan karakter seperti Pedoman Penghayatan dan Pengamalan Pancasila (P4), Badan Pembinaan Pendidikan Pelaksanaan Pedoman Penghayatan dan Pengamalan Pancasila (BP7), dan mata pelajaran pancasila pernah dihapuskan pada era reformasi. Penghapusan tersebut menyebabkan lembaga pendidikan tidak memiliki tanggung jawab dalam membentuk karakter sehingga banyak tafsir pancasila tidak beraturan. Akibatnya sebanyak 63 persen guru memiliki sikap intoleran dengan agama lain, tiga persen TNI terpapar ekstremisme dan tujuh kampus diketahui terpapar ekstremisme agama (Candraditya, 2020). Kurangnya pendidikan karakter juga berdampak pada krisis moral yang berakibat perilaku negatif di masyarakat seperti pergaulan bebas, penyalahgunaan obat-obatan terlarang, pencurian, tawuran, kekerasan dan lainnya.

Menurunnya pendidikan karakter sangat berbahaya bagi generasi muda, terutama untuk remaja. Di usia remaja, anak rentan melakukan tindakan kriminal atau kenakalan remaja. Di masa ini anak mengalami 
perubahan pada beberapa aspek sebagai seseorang dari masa kanak-kanak menuju masa dewasa sehingga remaja perlu melakukan penyesuaian (Santrock, 2011). Sebuah artikel milik Fakultas Kedokteran Masyarakat dan Keperawatan UGM menyebutkan tingkat kenakalan remaja di Indonesia mencapai 50\% dan menurut penelusuran Prof. Dr. Endang Ekowarni salah satu penyebabnya adalah kondisi psikologis anak yang berisiko melakukan agresivitas (Iro \& Wiwin, 2018).

Oleh karena itu, untuk mengurangi tingkat kenakalan remaja remaja diberi kesibukan dengan kegiatankegiatan yang bermanfaat dan positif, seperti mengikuti kegiatan kepramukaan. Kegiatan pramuka membentuk peserta didik memiliki kepribadian, kecakapan hidup, dan akhlak mulia pramuka melalui penghayatan dan pengamalan nilai-nilai kepramukaan. Gerakan pramuka sebagai sebuah lembaga pendidikan nonformal pendidikan kemasyarakatan, memperhatikan tahapan perkembangan dari peserta didik. Jenjang pendidikan pada gerakan pramuka digolongkan berdasarkan usia agar sesuai dengan tahapan perkembangan dari peserta didik. Hal itu dilakukan dengan membagi jenjang pendidikan kepramukaan menjadi empat golongan, yaitu Siaga (7-10 tahun), Penggalang (11-15 tahun), Penegak (16-20 tahun) dan Pandega (21-25 tahun). Metode kepramukaan dilakukan melalui pengamalan kode kehormatan pramuka, belajar sambil melakukan, kegiatan berkelompok, bekerjasama, dan berkompetisi, kegiatan yang menarik dan menantang, kegiatan di alam terbuka, kehadiran orang dewasa yang memberikan bimbingan, dorongan, dan dukungan; penghargaan berupa tanda kecakapan, dan satuan terpisah antara putra dan putri.

Kondisi di lapangan terdapat penyesuaian antara aturan nasional dengan aturan yang ada di pangkalan dimana gugusdepan itu berdiri. Pembina, guru, ataupun pihak yang mengatur berjalannya proses kepramukaan membuat bentuk-bentuk inovasi kegiatan atau metode dalam pembinaan kepada peserta didiknya untuk mencapai tujuannya. Namun, kenyataannya terdapat kasus-kasus yang menunjukkan ketidaktepatan praktek maupun kelalaian dalam kegiatan kepramukaan. Banyak pembina pramuka yang masih kurang sesuai dengan standar dalam membina peserta didik, beberapa diantaranya tidak memperhatikan metode dan materi kepramukaan. Pembina pramuka sekedar datang untuk menggugurkan kewajiban dan tidak menerapkan prinsip dasar kepramukaan dan metode kepramukaan untuk peserta didiknya. Kasus yang pernah terjadi adalah hilangnya empat peserta dan enam peserta meninggal dalam kegiatan susur sungai yang diikuti pramuka penggalang kelas tujuh dan delapan (Sucahyo, 2020). Kegiatan tersebut terlalu berbahaya untuk jenjang penggalang apalagi tanpa pendampingan orang dewasa. Kasus lainnya yang terjadi saat kegiatan Kursus Mahir Pembina Pramuka Tingkat Lanjut (KML) Gunung Kidul dimana salah seorang pembina yang ikut sebagai peserta mengajarkan tepuk pramuka berunsur SARA kepada peserta didik SD Negeri Timuran (Pertana, 2020). Hal tersebut sudah tidak sesuai dengan kode etik pramuka, yaitu dasa darma. Pembina yang tidak paham akan kebutuhan perkembangan dan metode kepramukaan yang tepat dapat mempengaruhi minat dan motivasi peserta didik untuk mengikuti kegiatan pramuka.

\section{Pramuka Penggalang}

Pramuka penggalang adalah anggota pramuka berusia 11 sampai 15 tahun. Jika dilihat dari jenjang sekolah formal, pramuka penggalang adalah siswa yang sedang duduk di bangku kelas lima dan enam SD, dan juga siswa SMP. Pada jenjang penggalang ini peserta didik memasuki tahap usia remaja awal sehingga pembina pramuka perlu memperhatikan tugas perkembangan menerima fisiknya, mencapai kemandirian emosional, mengembangkan keterampilan komunikasi interpersonal dan mulai bergaul dengan orang lain atau teman sebaya, percaya dengan kemampuannya dan menerima diri sendiri, 
menemukan seseorang yang ia jadikan model, dapat meninggalkan sikap kekanak-kanakan, menguatkan self-control atas prinsip dan nilai.

\section{Pendidikan Karakter}

Pendidikan karakter mengandung dua kata, yaitu pendidikan dan karakter. Pendidikan diartikan sebagai usaha terpadu untuk memanusiakan manusia, membentuk karakter agar peserta didik menjadi pribadi yang berbudaya intelektual (Sugiharto, 2013). Segala hal yang menjadi ciri khas suatu objek disebut karakter, begitu pula ciri khas yang dimiliki seseorang (Koesoema 2007 dalam Mu'in, 2014). Santrock (2011) menyebutkan bahwa pendidikan karakter adalah pendekatan pada pendidikan moral melalui pengajaran moral dasar agar peserta didik tidak terlibat perilaku amoral dan hal-hal yang berbahaya untuk orang lain dan dirinya sendiri. Pendidikan karakter juga diartikan sebagai usaha agar manusia dapat memahami, memiliki kepedulian, dan bertindak berdasarkan nilai etika (Lickona, 1992). Mu'in (2014) menyebutkan beberapa unsur terbentuknya karakter, yaitu sikap, emosi, kepercayaan, konsep diri (self-conception), kebiasaan, dan kemauan.

\section{Remaja (adolescence)}

Remaja didefinisikan sebagai tahapan pada kehidupan manusia dimulai dari masa puber hingga masa transisi peran sebagai orang dewasa, yang mana dialami manusia pada usia 10 hingga awal 20-an tahun dan selama masa tersebut manusia menjadi lebih tertarik dengan seks, menjadi lebih bijak dan mampu membuat keputusan. Remaja dibagi menjadi tiga fase, yaitu remaja awal (10-13 tahun), remaja tengah (14-17 tahun), dan remaja akhir (18-21) (Steinberg, 2017). Sebagai masa peralihan, remaja menunjukkan karakteristik perasaan yang mudah gelisah, mengalami pertentangan dengan orang lain, menyukai aktivitas kelompok, dorongan mencoba segala sesuatu (Ansori, 2008) .

\section{Developmentally Appropriate Practice}

Developmentally Appropriate Practice (DAP) merupakan praktik wacana perkembangan manusia yang diterapkan dalam dunia pendidikan. Adanya DAP bertujuan untuk memberikan pedoman bagaimana praktik pendidikan yang tepat dan sesuai dengan tahap perkembangan (Charlesworth, 1998). Pedoman DAP bukanlah suatu doktrin, namun digunakan sebagai perencanaan dalam menyediakan lingkungan belajar yang menyenangkan dan mendukung anak.

Sesuai dengan penjelasan diatas. Peneliti ingin mengetahui lebih dalam bagaimana gambaran penerapan Developmentally Appropriate Practice pada Pramuka Penggalang. Selain itu, mengetahui apa saja faktor yang mempengaruhi proses pembinaan karakter pramuka penggalang.

\section{Desain Penelitian}

\section{E T O D E}

Penelitian ini menggunakan metode penelitian kualitatif. Metode penelitian kualitatif dipilih karena sesuai dengan tujuan penelitian dimana peneliti ingin mengeksplorasi bagaimana pembina pramuka penggalang menerapkan Developmentally Appropriate Practice (DAP) pada pendidikan karakter kepada peserta didik remaja awal di SMP/MTs sederajat. Tipe penelitian ini adalah studi kasus, yaitu tipe penelitian yang mendalami suatu fenomena khusus dalam konteks yang terbatas (Bounded Context). Sedangkan studi kasus yang digunakan dalam penelitian ini adalah studi kasus intrinsik, artinya 
penelitian ini berfokus pada kasus itu sendiri karena kasus tersebut menunjukkan suatu hal yang unik dan tidak biasa (Stake, 1995 dalam Creswell, 2015).

\section{Partisipan}

Pemilihan partisipan pada penelitian ini menggunakan teknik purposive sampling. Purposive sampling adalah teknik pengambilan sampel dengan pertimbangan tertentu (Sugiyono, 2020). Dalam hal ini peneliti membuat kriteria khusus kemudian dari kriteria tersebut mencari partisipan yang paling memahami topik dan permasalahan. Kriteria partisipan yang ditentukan adalah pembina pramuka penggalang tingkat SMP/Sederajat yang telah mengikuti dan lulus KMD (Kursus Pembina Pramuka Mahir Tingkat Dasar). Selain itu, partisipan juga merupakan pembina pramuka yang terjun langsung menangani peserta didik.

Selama berjalannya penelitian, peneliti mendapatkan empat calon partisipan. Namun karena satu partisipan dianggap tidak menguasai topik, akhirnya dipilih tiga partisipan. Ketiga partisipan tersebut memiliki latar belakang dan asal daerah yang berbeda-beda agar mendapatkan data yang didapatkan bervariasi. Sebelum melakukan penggalian data, partisipan mendapatkan informent consent memberikan informasi dan persetujuan dari partisipan.

\section{Strategi Pengumpulan Data}

Peneliti menggali data dengan menggunakan wawancara kepada partisipan. Wawancara merupakan proses percakapan antara pewawancara dengan narasumber untuk memperoleh informasi dan melakukan eksplorasi terhadap pemaknaan subjektif yang dipahami individu yang berkenaan dengan topik yang diteliti (Poerwandari, 2013). Wawancara sendiri memiliki beberapa variasi, pada penelitian ini wawancara yang digunakan adalah wawancara dengan pedoman umum yang mana peneliti membuat pedoman yang digunakan sebagai pengingat dan checklist pada aspek yang digali. Peneliti juga menggunakan alat bantu perekam, dan alat tulis untuk mempermudah penggalian data.

\section{Analisis Data}

Setelah peneliti mendapatkan data partisipan dari hasil wawancara, kemudian peneliti melakukan transkrip wawancara untuk dianalisis. Analisis yang digunakan oleh peneliti adalah analisis tematik. Analisis tematik adalah salah satu cara mengolah informasi kualitatif melalui proses pengkodean informasi yang menghasilkan tema, indikator, kualifikasi yang terkait sehingga dapat mendeskripsikan suatu fenomena (Poerwandari, 2013). Peneliti melakukan pengorganisasian data dengan melakukan coding agar data sistematis dan terorganisasi secara detail agar dapat menggambarkan topik penelitian. Pendekatan yang digunakan peneliti untuk menganalisis data menggunakan pendekatan analisis data driven.

\section{H A S I L P E N E L I T I A N}

Dari ketiga partisipan ditemukan delapan metode yang digunakan untuk mendidik karakter, yaitu metode praktik, metode reward, metode punishment, metode kompetisi, metode pembiasaan, metode ceramah, metode modeling, dan metode mentoring. Delapan metode tersebut sesuai untuk diterapkan pada pramuka khususnya golongan penggalang dengan dasar menyesuaikan dengan usia perkembangan dan minat peserta didiknya. Sedangkan faktor yang mempengaruhi terbagi menjadi dua faktor besar, yaitu faktor lingkungan dan faktor personal. Faktor lingkungan meliputi lingkungan 
sekolah, lingkungan masyarakat, lingkungan keluarga, dan lingkungan pergaulan. untuk faktor personal terdiri dari peserta didik dan pembina pramuka itu sendiri. Faktor-faktor tersebut ada yang secara langsung memberi pengaruh dan tidak langsung memberi pengaruh pada berjalannya pendidikan karakter pramuka.

\section{Partisipan 1}

Partisipan 1 menggunakan kedelapan metode selama membina pramuka. Metode praktik yang diterapkan partisipan 1 dengan mengadakan kegiatan pramuka sebagai ajang untuk praktik ilmu kepramukaan sekaligus mendidik karakter peserta didik penggalang, karena nilai-nilai dasar seperti kedisiplinan, kemandirian, keterampilan selalu dimasukan dalam kegiatan kepramukaan. Partisipan 1 juga membentuk dewan penggalang agar mereka belajar mengelola organisasi dan memiliki rasa tanggung jawab. Metode reward dan punishment diterapkan sebagai bentuk penguatan atas perilaku positif maupun mengurangi perilaku negatif dari peserta didik. Partisipan 1 juga mengupayakan agar peserta didiknya dapat mengikuti perlombaan pramuka penggalang. Selama persiapan lomba, peserta didik menjadi lebih aktif dan memiliki inisiatif sendiri untuk membuat jadwal latihan, mengoordinasikan regu, dan selama lomba mereka akan terlatih untuk jiwa sportif dan kompetitif. Melalui pendidikan kepramukaan tersebut, peserta didik juga dibiasakan menerapkan nilai-nilai pramuka di kehidupan sehari-hari melalui metode pembiasaan. Metode ceramah partisipan 1 dilakukan dengan memberikan rambu-rambu mengenai apa yang perlu dan yang tidak perlu diakses dalam internet, menjelaskan peraturan penggunaan hasduk, memberikan pemahaman kepada peserta didik alasan menghormati bendera merah putih dengan menceritakan sejarah dan perjuangan pahlawan, memberi pemahaman kepada peserta didik yang suka melakukan bullying terhadap peserta didik dengan kebutuhan khusus. Sebagai pembina pramuka, partisipan 1 harus menjadi contoh yang baik bagi peserta didiknya. Hal itu karena anak remaja membutuhkan seseorang dapat menjadi sosok teladan bagi mereka sehingga perlu diterapkan metode modeling selama kegiatan pramuka maupun diluar kegiatan pramuka. Terakhir adalah metode mentoring. Partisipan 1 menerapkan dengan melakukan pendekatan kepada peserta didik remaja sebagai teman dekat mereka. Selain itu partisipan 1 mendorong dan memberi kesempatan kepada peserta didik untuk berani berbicara dan berpendapat.

Terdapat beberapa faktor yang dapat mempengaruhi berjalannya pembinaan karakter pramuka penggalang menurut partisipan 1. Faktor pertama berasal dari lingkungan, yaitu lingkungan sekolah, keluarga, pergaulan dan peserta didik. Sekolah memiliki kebijakan untuk memberi izin kegiatan dan memberikan dana kegiatan pramuka. Hal tersebut berdampak pada perlombaan yang akan diikuti oleh peserta didik partisipan 1 . Untuk dapat mengikuti perlombaan, partisipan sempat mengajak peserta didiknya untuk iuran karena tidak mendapatkan pendanaan dari sekolah. Partisipan 1 merasa pihak sekolah memandang pramuka sebagai kegiatan formalitas saja. Lingkungan keluarga berupa kondisi ekonomi dan cara orang tua mendidik anaknya mempengaruhi karakter anak dimana hal itu memengaruhi proses pendidikan karakter di pramuka juga. Pengaruh lingkungan juga datang dari bentuk pergaulan, dimana anak-anak sangat mudah dipengaruhi oleh teman sebayanya. Partisipan 1 juga merasa terbantu ketika dewan penggalang ikut mengkondisikan teman-temannya sendiri. Kemudian faktor dari personal pembina pramuka berupa latar belakang pendidikan berpengaruh pada bagaimana pembina mendidik peserta didiknya. partisipan 1 adalah seorang mahasiswa psikologi. Cara partisipan 1 membina pramuka selalu memperhatikan teori-teori psikologi yang ia pelajari. Fokus yang diambil partisipan 1 selama mendidik karakter adalah melatih kedisiplinan peserta didiknya. faktor personal yang kedua dari minat peserta didiknya sendiri. Beberapa kelas umumnya menunjukkan 
keaktifannya mengikuti latihan pramuka rutin. Selain itu peserta didik menjadi lebih aktif dan memiliki inisiatif saat persiapan lomba pramuka.

\section{Partisipan 2}

Beberapa metode yang dilakukan partisipan 2 untuk mendidik karakter peserta didiknya yaitu metode praktik, ceramah, modeling, mentoring, dan dengan mengikuti lomba pramuka penggalang. Pelaksanaan metode praktik dilakukan dengan memberikan tugas sebagai petugas upacara atau dewan penggalang, mengagendakan malam renungan 17 agustus di makam Ir. Soekarno di Kota Blitar, mengisi dan menguji SKU (Syarat Kecakapan Umum), mengadakan kegiatan yang mengandung unsur pendidikan karakter peserta didik seperti program khataman Al-Quran, dan bersih-bersih masjid warga setempat. Selain itu partisipan 2 juga mendorong peserta didiknya untuk beribadah diawal waktu dan mengutamakan jamaah. Kemudian peserta didik mengikuti perlombaan pramuka penggalang agar peserta didik juga menunjukkan sikap proaktif selama masa persiapan lomba dan pelaksanaan lomba pramuka sehingga peserta didik dapat bertahan dalam perlombaan. Metode ceramah digunakan partisipan 2 dengan partisipan menyampaikan materi secara lisan, menyampaikan nasihat saat amanah upacara berlangsung, menceritakan sejarah pahlawan, dan memberi pemahaman kepada peserta didik secara lisan bahwa setiap materi dan kegiatan kepramukaan memiliki hubungan nilai religius jika diterapkan dengan baik. Partisipan 2 juga menerapkan metode modeling seperti memberi contoh kepada peserta didik mengenai cara berpakaian pramuka yang baik dan rapi. Selanjutnya partisipan 2 melakukan mentoring kepada dewan penggalang dimana partisipan 2 mengevaluasi dewan penggalang. Partisipan 2 memberikan kesempatan kepada peserta didik untuk membuat keputusan dengan tidak terlalu mengintervensi.

Faktor lingkungan sekolah sangat dirasakan oleh partisipan 2 selama membina pramuka. Partisipan 2 memandang pihak sekolah terlalu berambisi untuk berprestasi sehingga pendidikan kepramukaan diukur dari jumlah prestasi yang didapatkan ketika lomba pramuka. Partisipan 2 berpendapat bahwa hal tersebut tidak sesuai dengan tujuan Gerakan Pramuka karena terlalu fokus pada prestasi lomba saja. Di lingkungan keluarga, jika orang tua tidak suka dan tidak mendukung anaknya mengikuti pramuka, maka anaknya tidak bisa mengikuti pendidikan kepramukaan bersama pendidikan karakter. Disamping itu banyak orang tua yang terlalu sering mengunjungi anaknya ketika berkemah, bahkan tidak memperdulikan jam kunjung. Partisipan 2 menilai peserta didik yang terlalu sering dikunjungi ketika kegiatan kemah menunjukkan kemandirian yang kurang dibanding peserta didik yang tidak dijenguk oleh keluarganya. Selanjutnya faktor personal peserta didik ditunjukkan dari minat peserta didik mengikuti pramuka, karena pembina pramuka akan lebih mudah karena adanya keinginan dari peserta didik sendiri untuk mengikuti kegiatan pramuka. Selain itu, riwayat penyakit yang diderita peserta didik juga mempengaruhi keikutsertaannya selama kegiatan pramuka. Partisipan 2 menyebutkan peserta didik ada yang memiliki penyakit jantung dan sering terjadi kesurupan massal. Hal tersebut berdampak pada pembatasan kegiatan pramuka. Terakhir faktor yang berasal dari pembina pramuka itu sendiri adalah kesibukan dan karakter yang dimilikinya. Selama membina pramuka, partisipan 2 tidak pernah memaksa kehendaknya kepada peserta didik. Ia memberikan kesempatan peserta didik untuk melakukan eksplorasi dan berinovasi.

\section{Partisipan 3}

Pendidikan karakter yang dijalankan partisipan 3 untuk peserta didiknya menggunakan enam metode. Metode pertama yaitu praktik yang dilakukan melalui kegiatan yang diselenggarakan. Setiap kegiatan kepramukaan melatih keterampilan dan mendidik karakter positif bagi peserta didik. Selama kegiatan 
berkemah peserta didik akan belajar memasak, membangun tenda, dll. Ketika mereka mengalami masalah saat berkemah seperti terbatasnya sumber air, maka akan belajar untuk membuat solusi dan memanajemen air yang ada. Peserta didik dapat belajar mengelola organisasi, meningkatkan rasa tanggung jawab dan kepemimpinan dengan pengalamannya di dewan penggalang. Praktik lain yang menumbuhkan karakter religius, peduli sesama dan lingkungan dengan mendorong peserta didik menunaikan sholat tepat waktu, mengadakan kegiatan bagi-bagi takjil, berbagi rezeki ke orang yang kurang mampu, dan praktik menanam dan merawat tumbuhan di sekolah secara langsung. Pada saat materi semaphore, partisipan 3 memberi reward agar mereka berani untuk praktik di depan temantemannya. Metode punishment juga diterapkan partisipan 3 untuk menertibkan peserta didiknya. selanjutnya melalui metode ceramah, partisipan 3 menyampaikan materi pendidikan karakter pramuka kepada peserta didik dengan menghubungkan dengan kehidupan sehari-hari. Dengan begitu peserta didik lebih mudah mengingat materi dan dapat menjalankannya karena lebih dekat dengan kehidupan sehari-hari yang dialami peserta didik. Sebagai pembina pramuka penggalang, partisipan 3 selalu memberi dukungan dan motivasi kepada peserta didiknya ketika latihan rutin, perlombaan, dll. Partisipan 3 juga sering mengajak bicara kepada peserta didik yang terlihat murung untuk mengetahui masalah dan memberinya semangat. Untuk mendidik karakter, partisipan 3 perlu menunjukkan contoh yang baik kepada peserta didiknya yaitu dengan metode modeling. Terakhir metode mentoring dilakukan dengan membuat kegiatan pendalaman dasa darma. Kegiatan ini dilaksanakan dengan membuat sepuluh pos sesuai jumlah poin dasa darma. Peserta didik satu persatu akan datang ke pos tersebut untuk melakukan pendalaman poin dasa darma bersama pembina pramuka yang telah dibagi di setiap pos.

Faktor yang mempengaruhi pendidikan karakter di pramuka terdiri dari faktor lingkungan dan personal. Faktor lingkungan yang pertama adalah lingkungan sekolah. Selama pihak sekolah mendukung kegiatan pramuka, segala bentuk pendidikan kepramukaan yang bertujuan membentuk karakter peserta didik pun dapat berjalan karena mendapat izin dan bantuan dana dari sekolah. Pihak sekolah mendorong prestasi pramuka dengan mengalokasikan dana untuk mengikuti perlombaan pramuka penggalang. Adanya kerja sama antara BK (Bimbingan Konseling) dan pembina pramuka membantu mengontrol dan mendisiplinkan peserta didik kegiatan pramuka maupun di luar latihan atau kegiatan pramuka. Namun partisipan 3 terkendala aturan dari Dinas Pendidikan Kota Surabaya yang melarang kegiatan pramuka di luar kota. Faktor selanjutnya berasal dari masyarakat dimana sekolah berada dilingkungan TNI AL sehingga secara tidak langsung mendapatkan keamanan dan penjagaan di area tersebut, terutama ancaman penyalahgunaan narkoba. Faktor lingkungan keluarga berupa bentuk dukungan dari orang tua kepada anaknya yang mengikuti ekstrakurikuler pramuka di sekolah. Partisipan 3 juga melakukan pendekatan terhadap orang tua peserta didik. Partisipan 3 sesekali mengunjungi rumah peserta didik dan bertemu dengan orang tua peserta didik. Komunikasi antara pembina pramuka dengan orang tua peserta didik inilah yang menjadi strategi koping partisipan 3 untuk memberikan kepercayaan kepada orang tua bahwa anaknya benar-benar mengikuti kegiatan pramuka dan pembina pramuka menjamin keselamatan peserta didik. Faktor lingkungan pergaulan juga memberi pengaruh kepada setiap peserta didiknya dimana anak remaja mudah untuk mengikuti arus pergaulannya sehingga jika mereka salah memilih pergaulan akan berdampak buruk bagi karakternya. Kemudian faktor personal pembina pramuka yang memiliki karakter mengayomi peserta didiknya. partisipan 3 selalu menggunakan pendekatan kekeluargaan sehingga memiliki ikatan yang erat dengan peserta didiknya. Partisipan 3 mengadaptasi cara membina dan mendidik dari pengalamannya masa kecil saat ia ikut membaca Al-Quran. Partisipan terinspirasi dengan bagaimana lingkungan kekeluargaan dan kekompakan saat di tempat belajar membaca Al-Quran. 


\section{I S K U S I}

Dari penelitian di atas diketahui pembina pramuka penggalang merancang suatu kegiatan yang didalamnya memiliki unsur pendidikan karakter. Metode pratik yang dilakukan pembina pramuka dengan mengadakan kegiatan kepramukaan maupun non kepramukaan. Metode ini berguna sebagai proses learning by doing, dimana peserta didik juga mendapatkan pengalaman langsung atas pembentukan karakter mereka secara sadar maupun tidak sadar.

Berkemah merupakan salah satu kegiatan yang tidak asing lagi bagi seorang pramuka. Melalui kegiatan perkemahan banyak pembelajaran yang peserta didik dapatkan secara praktik, seperti yang dilakukan partisipan yaitu melatih peserta didik untuk hidup mandiri, terampil, kreatif dan memiliki kemampuan manajemen yang baik. Selain itu, berkemah juga dapat melatih peserta didik mampu problem solving. Kegiatan perkemahan harus didesain yang menyenangkan untuk menutupi rasa ketidaknyamanan dan rasa takut saat berkemah. Dengan demikian, peserta pun mendapat manfaatnya membentuk karakter (Baker, dkk., 2018). Sedangkan untuk memupuk karakter religius, partisipan 2 dan 3 menekankan kegiatan keagamaan dalam pendidikan kepramukaan, seperti sholat berjamaah di awal waktu sebelum upacara penutupan latihan rutin pramuka, khataman Al-Quran. Marini dkk. (2018) melakukan penelitian yang menyebutkan bahwa ketersediaan fasilitas peribadatan, kegiatan keagamaan, dan simbol keagamaan mendukung pembentukan karakter religius peserta didik berupa ketaatan beribadah. Kegiatan yang partisipan 2 lakukan bersama peserta didiknya sebagai bentuk kepedulian terhadap lingkungan sekitar berupa bersih-bersih mushola warga. Begitu pula dengan partisipan 3 yang mengadakan kegiatan bagi-bagi takjil, berbagi rezeki kepada orang yang kurang mampu, dan merawat tanaman selama dua minggu di sekolah. Selanjutnya partisipan membentuk dewan penggalang untuk belajar menjalankan organisasi pramuka di sekolah. melalui Kegiatan pembelajaran melalui praktik secara langsung tersebut membuka pintu bagi peserta didik memperdalam kemampuan dan mendapatkan pengalaman yang tidak ia dapatkan sebelumnya di dalam pembelajaran berbasis kelas (Brown dkk, 1989 dalam Honig \& Honsa, 2020).

Partisipan 1 dan 3 memberi reward untuk memotivasi peserta didik agar berani menjawab pertanyaan dan berani tampil di depan teman-temannya. Penghargaan yang partisipan berikan tidak hanya berupa barang, namun juga dapat berupa kata-kata apresiasi kepada peserta didik. Tujuannya agar terjadi penguatan perilaku positif pada peserta didik. Reward tersebut berguna untuk stimulus bagi individu dalam meningkatkan motivasi intrinsik. Begitu juga dengan reward verbal, yang dapat meningkatkan motivasi melakukan suatu aktivitas (Cameron \& Pierce, 1994).

Selain reward, pemberian punishment (hukuman) juga diterapkan partisipan saat kegiatan pramuka untuk membentuk perilaku individu. Hukuman yang diberikan kepada peserta didik yang tidak tertib berupa membersihkan sampah, selanjutnya untuk pelanggaran besar akan diserahkan kepada pihak BK sekolah. Hukuman diberikan kepada peserta didik yang melanggar aturan untuk memberikan efek jera dan memberikan dampak pada pembentukan karakter taat pada aturan (Misriyah, 2015).

Pramuka penggalang memiliki minat yang tinggi terhadap lomba pramuka. Oleh karena itu, mengikuti kompetisi pramuka menjadi daya tarik tersendiri bagi pramuka penggalang. Kompetisi pramuka tidak hanya sebagai ajang bersaing antar pramuka penggalang, namun menjadi tempat mendidik pramuka penggalang bermain sportif dan lebih giat dalam berlatih. Oleh karena itu partisipan 1 dan 2 mengusahakan agar peserta didiknya dapat mengikuti kompetisi pramuka penggalang. Melalui kegiatan 
kompetisi, peserta didik terlatih untuk kompetitif dan tetap menjunjung sportifitas. Selain itu dengan mendelegasikan peserta didik lomba pramuka akan mempertemukan mereka dengan pramuka penggalang dari sekolah lain, sehingga termotivasi menjadi pramuka yang lebih baik lagi. Hal tersebut terjadi karena adanya dorongan dalam diri peserta didik untuk berkembang dan berubah menjadi lebih baik, serta memotivasi peserta didik untuk mengembangkan bakat dan kemampuan peserta didik. Terdapat empat hal yang akan terpupuk pada diri peserta didik melalui metode kompetisi, yaitu membangun dan membudayakan semangat kerja keras, semangat kompetisi yang dipadukan dengan budaya kooperasi, terbiasa dengan berpikiran positif, dan sikap sportif (Yusuf, 2020).

Pendidikan karakter dengan metode ceramah diterapkan melalui penyampaian langsung secara lisan kepada peserta didik berupa wawasan moral, aturan yang diterapkan, atau melalui sebuah cerita. Metode ceramah dalam menyampaikan materi moral sangat efisien dan fleksibel dimana pembina menyampaikan mana yang baik dan tidak baik untuk dilakukan (Kaur, 2011). Saat upacara partisipan 2 sering menyampaikan nasihatnya kepada peserta didik. Diterima atau tidaknya nasihat dipengaruhi oleh bagaimana hubungan kedua belah pihak yaitu, pemberi nasihat dan penerima nasihat. Hubungan tersebut nampak pada bagaimana penasihat menyampaikan nasihatnya dan bagaimana penerima nasihat melihat moral pemberi nasihat (Shaw \& Hepburn, 2013). Ketiga partisipan sama-sama menceritakan tentang perjuangan pahlawan kemerdekaan untuk memupuk rasa cinta tanah air peserta didik. Cerita tentang pahlawan nasional dapat diceritakan untuk dipelajari dan menginspirasi orangorang yang mendengarnya (Noddings, 1994).

Pendidikan karakter tidak cukup hanya penyampaian gagasan saja, namun juga perlu adanya suatu perbuatan yang dilakukan berulang-ulang sehingga membentuk karakter (Hendriana \& Jacobus, 2016). Kegiatan yang dilakukan secara teratur dan berulang menghasilkan perubahan perilaku yang menetap. Melalui kegiatan pramuka, partisipan 1 yakin peserta didik akan terbiasa berperilaku baik jika mengikuti aturan ataupun kode etik pramuka dalam kehidupan sehari-hari.

Partisipan sama-sama menerapkan metode modeling untuk membentuk karakter peserta didik pramuka. Agar peserta didik disiplin dalam segala hal, partisipan 1 juga harus menunjukkan sikap disiplin. Partisipan 2 yang selalu tampil berseragam rapi agar menjadi contoh peserta didik yang lain saat kegiatan pramuka. Sejalan dengan hal tersebut. Begitu juga partisipan 3 meminta pembina pramuka yang lainnya tidak bermain handphone saat kegiatan pramuka berlangsung agar peserta didik juga tidak bermain handphone dan menghargai pemateri. Peserta didik melihat guru sebagai sosok panutan yang mengatakan kebenaran, menjalani kehidupan yang bermoral dan memberikan rasa kepercayaan antara guru dengan peserta didik (Lumpkin, 2008).

Metode selanjutnya adalah mentoring, dimana proses pendampingan ini yang dilakukan bersifat positif dan mengembangkan hubungan antara mentor (pembina pramuka) dengan mentee (peserta didik) Agar peserta didik mendapatkan pengalaman positif, proses pendampingan perlu melibatkan rasa empati, perhatian, dan menjadi pendengar aktif. Bentuk pendampingan partisipan 2 dengan memberi kebebasan kepada peserta didiknya untuk berinovasi dan berkreasi, namun tetap berada dalam pengawasan partisipan 2. Partisipan 2 sekedar memberi usulan yang bersifat membangun. Setelah itu partisipan SYT memberi evaluasi dan koreksi kepada peserta didik. Sedangkan partisipan 1 dan 3 menyatakan bahwa pembina pramuka harus menjadi teman atau orang tua bagi peserta didiknya. Kedekatan antara partisipan 3 dengan peserta didik pramuka penggalang tidak hanya di dalam kegiatan pramuka, namun di luar itu partisipan 3 memiliki hubungan baik dan peserta didik menganggap partisipan 3 sebagai orang tua kedua mereka. Oleh karena itu proses pendampingan dan bimbingan 
akan lebih mudah dilakukan. Proses dukungan aktif dilakukan mentor dengan bijak, seperti menjadi pendengarnya tanpa menghakiminya, membantu mengatasi masalah yang dialami peserta didik, sehingga peserta didik merasakan adanya rasa saling memiliki dan peduli antara mentor dan mentee (Kazlauskaite dkk, 2020).

Pendidikan karakter di pramuka tidak terlepas dari lingkungan sekolah sebagai tempat utama menjalankan pendidikan kepramukaan, termasuk dukungan yang ada didalamnya. Partisipasi komite sekolah terhadap ekstrakurikuler sekolah untuk mendukung pencapaian tujuan kegiatan dan layanan kegiatan ekstrakurikuler (Anggraini, dkk, 2018). Partisipan 2 dan 3 mendapatkan dukungan berupa izin dan pendanaan kegiatan dari sekolah. Sedangkan partisipan 1 tidak sepenuhnya mendapat bantuan dana karena pihak sekolah memandang pramuka sebagai ekstrakurikuler formalitas di sekolah.

Letak sekolah yang berada di komplek TNI AL (Angkatan Laut) menjadi keuntungan tersendiri bagi partisipan 3. Secara tidak langsung sekolah mendapatkan keamanan dari ancaman pengaruh luar, seperti minuman keras, narkoba, tawuran pelajar dan lain-lain. Smith dkk. (1997), melakukan penelitian yang menyebutkan bahwa lingkungan dapat menjadi mitra yang baik untuk mendukung proses pendidikan.

Faktor keluarga tampak dari bagaimana sikap orang tua terhadap kegiatan pramuka. Orang tua peserta didik tidak seluruhnya mendukung anaknya aktif mengikuti kegiatan pramuka. Akhirnya peserta didik juga tidak dapat mengikuti rangkaian pendidikan kepramukaan khususnya pendidikan karakternya dengan baik. Orang tua tentu memiliki kepercayaan-kepercayaan yang diwariskan kepada anakanaknya, sehingga peran orang tua sebagai pengasuh akan mempengaruhi perilaku anaknya (Gea, 2011). Orang tua yang sering mengunjungi anaknya tanpa memperhatikan jam kunjung saat berkemah di sekolah, menunjukkan sikap anak yang kurang mandiri selama berkemah. Sikap orang tua yang terlalu mengontrol dan berlebihan memberikan bantuan kepada anak dapat mengganggu otonomi remaja (Poulin, dkk., 2012).

Anak remaja banyak menghabiskan waktu dengan teman sebayanya sehingga apa yang dipikirkan dan dilakukan oleh teman sebayanya akan lebih berpengaruh terhadap dirinya (Knoll dkk., 2017). Pembina pramuka penggalang pun perlu mengawasi peserta didik selama kegiatan pramuka maupun di luar kegiatan pramuka untuk mengantisipasi faktor lingkungan pergaulan.

Minat mengikuti kegiatan pramuka termasuk faktor personal dari peserta didik itu sendiri. Bagi peserta didik yang minat dan aktif tentu saja akan lebih optimal dalam mengikuti pendidikan kepramukaan. Peserta didik dengan minat yang tinggi akan mencapai pemahaman pada pembelajarannya, disamping itu perlu dibuat daya tarik kegiatan yang menantang, memancing rasa ingin tahu, mendorong kontrol diri pada peserta didik, dan memperhatikan fungsi dari aktivitasnya (Schiefele, 1991). Selain itu kesehatan peserta didik juga menjadi pertimbangan untuk mengadakan kegiatan seperti berkemah. Partisipan 2 mengkhawatirkan kesehatan peserta didiknya yang memiliki riwayat sakit jantung dan seringnya terjadi kesurupan massal di sekolah. hal tersebut menunjukkan kesehatan yang rendah dapat mempengaruhi aspek pendidikan (Zimmerman dkk, 2016).

Selanjutnya faktor personal pembina pramuka ditunjukkan dengan karakter atau gaya mengajar pembina yang berbeda-beda. Gaya mengajar tersebut juga dipengaruhi latar belakang partisipan. Partisipan 1 merupakan seorang mahasiswa di fakultas psikologi sehingga setiap kegiatannya berlandaskan keilmuannya. partisipan 2 mengarah pada karakter religius, karena pangkalannya pramukanya berada di lingkungan madrasah tsanawiyah. Kemudian partisipan 3 mengutamakan 
kekeluargaan di pramuka karena terinspirasi dari pengalaman masa kecilnya saat belajar membaca AlQuran yang sangat kental dengan budaya kekeluargaannya. Tschannen-Moran, dkk. (1998 dalam Garvis \& Pendergast 2010) menyebutkan bahwa Pengalaman masa lalu merupakan salah satu yang berkontribusi perkembangan self-efficacy seorang guru.

\section{S I M P U L A N}

Berdasarkan hasil dari penelitian, metode pendidikan karakter pada pramuka penggalang yang sesuai dengan perkembangan terdiri dari metode praktik, metode reward, metode punishment, metode kompetisi, metode pembiasaan, metode ceramah, metode modeling, dan metode mentoring. Namun dari semua metode tersebut, empat metode diantaranya sama-sama digunakan oleh ketiga partisipan, yaitu metode praktik, ceramah, modeling, dan mentoring. Metode reward dan punishment bersifat penguat perilaku pada peserta didik. Nilai-nilai pramuka yang termuat di dalam kegiatan pramuka juga akan tertanam pada diri peserta didik. Setiap metode perlu dilakukan berulang kali hingga membentuk suatu kebiasan yang menetap pada peserta didik.

Sedangkan faktor yang mempengaruhi pendidikan karakter pramuka terdiri dari faktor lingkungan dan personal. Antara lingkungan sekolah, keluarga, masyarakat dan pergaulan akan memberikan dampak pada karakter peserta didik. Disamping itu faktor personal pembina pramuka sebagai tenaga pendidik menentukan bagaimana jalannya metode yang digunakan. Minat dan kesehatan peserta didik faktor personal peserta didik juga memberi pengaruh. Semakin tinggi minat peserta didik mengikuti setiap kegiatan pramuka dan diimbangi dengan kesehatan membuat pendidikan karakter pramuka berjalan lebih optimal.

Penelitian ini menggali data terkait metode pendidikan karakter pramuka penggalang yang digunakan pembina pramuka saat ini dan tidak membahas pengaruh suatu jenis metode terhadap karakter peserta didik, misalnya dampak metode kompetisi pada sportifitas peserta didik. Oleh karena itu penelitian selanjutnya berkesempatan untuk menyempurnakannya dengan membedah secara detail tahap dan proses penerapan salah satu metode pendidikan kepramukaan.

\section{U C A P A N T ERIMAKASIH}

Penulis mengucapkan terimakasih kepada Bapak Iwan Wahyu Widayat, Ibu Dewi Retno Suminar, Bapak Duta Nurdibyanandaru yang telah membimbing penulis hingga tahap ini. Juga kepada orang tua penulis yang telah merawat dan membesarkan penulis hingga menjadi pribadi seperti ini.

\section{DEKLARAS I POTENSI TERJADINYA KONFLIK KEPENTINGAN}

Mohamad Nur Setyo dan Iwan Wahyu Widayat tidak bekerja, menjadi konsultan, memiliki saham, atau menerima dana dari perusahaan atau organisasi manapun yang mungkin akan mengambil untung dari diterbitkannya naskah ini.

\section{PUST AKA ACUAN}

Ahmadi, R. (2014). Pengantar Pendidikan: Asas dan Filsafat Pendidikan. Yogyakarta: Ar-Ruzz Media. 
Anggraini, F. L., Hanurawan, F., \& Hadi, S. (2018). Partisipasi Komite Sekolah pada Kegiatan Ekstrakurikuler. Jurnal Pendidikan, 544-551.

Ansori, A. (2008). Psikologi Perkembangan. Jakarta: Rineka Cipta.

Baker, A., Fullagar, S., \& O’Brien, W. (2018). All In Good Fun: Governing Camp Experiences Through Discourses of "Good" and "Fun." Leisure Studies, 1-14.

Cameron, J., \& Pierce, W. D. (1994). Reinforcement, Reward, and Intrinsic Motivation: A Meta-Analysis. Review of Educational Research, 363-423.

Candraditya, V. J. (2020). Andai P4, BP7, hingga Mata Pelajaran Pancasila Tak Dihapus, Karakter Bangsa Tidak Separah Hari Ini. Retrieved March 7, 2021, from www.tribunnews.com website: https://www.tribunnews.com/nasional/2020/03/07/andai-p4-bp7-hingga-mata-pelajaranpancasila-tak-dihapus-karakter-bangsa-tidak-separah-hari-ini

Charlesworth, R. (1998). Developmentally Appropriate Practice is for Everyone. Childhood Education, 278-282.

Creswell, J. W. (2015). Penelitian Kualitatif dan Riset: Memilik Di Antara Lima Pendekatan. Yogyakarta: Pustaka Pelajar.

Garvis, S., \& Pendergast, D. (2010). Middle Years Teachers' Past Experiences of The Arts: Implications for Teacher Education. Australian Journal of Music Education, 28-40.

Gea, A. A. (2011). Enculturation Pengaruh Lingkungan Sosial Terhadap Pembentukan Perilaku Budaya Individu. Humaniora, 139-150.

Hendriana, E. C., \& Jacobus, A. (2016). Implementasi Pendidikan Karakter di Sekolah melalui Keteladanan dan Pembiasaan. Jurnal Pendidikan Dasar Indonesia, 25-29.

Honig, M. I., \& Honsa, A. (2020). Systems-Focused Equity Leadership Learning: Shifting Practice Through Practice. Journal of Research on Leadership Education, 192-209.

Indonesia, P. R. (2003). Undang-Undang Republik Indonesia Nomor 20 Tahun 2003 Tentang Sistem Pendidikan Nasional. Jakarta, Indonesia: Kementrian Pendidikan dan Kebudayaan.

Iro, \& Wiwin. (2018). Kekerasan Remaja Indonesia Mencapai 50 Persen. Retrieved March 14, 2021, from fk.ugm.ac.id website: https://fk.ugm.ac.id/kekerasan-remaja-indonesia-mencapai-50-persen/

Kaur, G. (2011). Study and Analysis of Lecture Model of Teaching. International Journal of Educational Planning \& Administration., 8-13.

Kazlauskaite, V., Braughton, J. E., Weiler, L. M., Henry, K. L., \& Lucas-Thompson, R. (2020). Adolescents' experiences of mentor alliance and sense of belonging in a sitebased mentoring intervention. Children and Youth Services Review, 1-10. 
Knoll, L. J., Leung, J. T., Foulkes, L., \& Blakemore, S.-J. (2017). Age-related Differences in Social Influence on Risk Perception Depend on The Direction of Influence. Journal of Adolescence, 53-63.

Lickona, T. (1992). Educating for Character: How Our Schools Can Teach Respect and Responsibility. New York: Bantam Doubleday Dell Publishing Group Inc.

Lumpkin, A. (2008). Teachers as Role Models Teaching Character and Moral Virtues. Journal of Physical Education, Recreation \& Dance, 79(2), 45-50. https://doi.org/10.1080/07303084.2008.10598134

Marini, A., Safitri, D., \& Muda, I. (2018). Teachers as Role Models Teaching Managing School Based on Character Building in The Context of Religious School Culture and Moral Virtues. Journal of Social Studies Education Research, 274-294.

Misriyah, S. (2015). Implementation and Implication of Reward and Punishment Toward Character Education at Senior High School in Pemalang. Hikmatuna, 68-98.

Mu'in. (2014). Pendidikan Karakter: Konstruksi Teoritik dan Praktik. Jogjakarta: Ar-Ruzz Media.

Noddings, N. (1994). Conversation as Moral Education. Journal of Moral Education, 107-118.

Pertana, P. R. (2020). Pembina Pramuka di Gunungkidul Cabuli 7 Siswi SMP Saat Kemah. Retrieved January 10, 2021, from news.detik.com website: https://news.detik.com/berita-jawa-tengah/d4854218/pembina-pramuka-di-gunungkidul-cabuli-7-siswi-smp-saat-kemah

Poerwandari, E. K. (2013). Pendekatan Kualitatif Untuk Penelitian Perilaku Manusia. Depok: LPSP3 UI.

Poulin, F., Nadeau, K., \& Scaramella, L. V. (2012). The Role of Parents in Young Adolescents' Competence With Peers: An Observational Study of Advice Giving and Intrusiveness. Merrill - PalMer Quarterly, 437-462.

Santoso, S. I. (1981). Pembinaan Watak Tugas Utama Pendidikan (U. Press, Ed.). Jakarta.

Santrock, J. W. (2011). Lise-Span Development Thirteenth Edition (13th ed.). New York: McGraw-Hill Companies.

Schiefele, U. (1991). Interest, Learning, and Motivation. Educational Psychologist, 299-323.

Shaw, C., \& Hepburn, A. (2013). Managing the Moral Implications of Advice in Informal Interaction. Research on Language and Social Interaction, 344-362.

Smith, E. P., Connell, C. M., Wright, G., Sizer, M., \& Norman, J. M. (1997). An Ecological Model of Home, School, and Community, Partnerships: Implications for Research and Practice. Journal of Educational and Psychological Consultation, 339-360.

Steinberg, L. (2017). Adolescence Eleventh Edition (11th ed.). New York: McGraw-Hill Education.

Sucahyo, N. (2020). Susur Sungai Pramuka: Setidaknya 6 Meninggal, 4 Hilang. Retrieved February 21, 
2021, from www.voaindonesia.com` website: https://www.voaindonesia.com/a/susur-sungaipramuka-setidaknya-6-meninggal-4-hilang-/5298358.html

Sugiharto, B. (2013). Humanisme dan Humaniora. Bandung: Pustaka Matahari.

Sugiyono. (2020). Metode Penelitian Kualitatif untuk Penelitian yang Bersifat: Eksploratorif, Enterpretif, Interaktif dan Konstruktif. Bandung: Alfabeta.

Yusuf, M. (2020). Model Pembelajaran Kompetisi dalam Meningkatkan Motivasi Belajar Siswa. Asosiasi Dosen Tarbiyah, 61-73.

Zimmerman, E. B., Woolf, S. H., Blackburn, S. M., Kimmel, A. D., Barnes, A. J., \& Bono, R. S. (2016). The Case for Considering Education and Health. Urban Education, 744-773. 